\title{
A DESESTATIZAÇÃO DO PORTO DE SANTOS PARA A MODERNIZAÇÃO DA CADEIA LOGÍSTICA PORTUÁRIA
}

Lenilton Jordão da Silva

Barachel em Administração de Empresas, com MBA em

Controladoria e Finanças e em Gestão de Pessoas.

Diretor de recursos humanos e sustentabilidade.

E-mail: leniltonjordao@hotmail.com 


\section{A MELHORA DO PORTO DE SANTOS VAI ALÉM DE UM PROCESSO REGULATÓRIO E AJUSTE DE PREMISSAS JURÍDICAS E REQUER MAIOR EFICIÊNCIA OPERACIONAL E CAPACITAÇÃO PROFISSIONAL}

Não é possível obter eficiência operacional da cadeia logística sem desestatizar, melhorar, privatizar o sistema portuário. Para modernizar o sistema portuário, é necessário mitigar a insegurança jurídica. Atualmente, uma dificuldade que se verifica nos portos públicos diz respeito à realização de investimentos nas áreas comuns, pois a autoridade portuária não tem recursos necessários para investimentos como dragagem e melhorias de acessos, sejam terrestres ou aquaviários.

Alguns terminais privados, ainda que façam os próprios investimentos, dependem de melhorias que a autoridade portuária não consegue fazer. Dessa forma, a desestatização tende a alterar esse cenário, visto que os terminais privados e outros concessionários dos portos terão condições de executar de forma mais eficiente o planejamento de melhorias nas estruturas e nas áreas comuns dos portos.

Se esse processo acontecer, será um modelo disruptivo que pode elevar o porto a outro patamar operacional e de eficiência logística, que pode fazer que os portos tenham competitividade compatível a outros portos mundiais, sendo um momento oportuno, já que uma série de mudanças vêm ocorrendo.

A pandemia trouxe novas necessidades aos portos, como o reforço em tecnologia, a transformação digital, por exemplo, que já estava na pauta das empresas, seja por meio da inteligência artificial, da computação em nuvem, da automação e da cyber security, surgindo novas demandas de projetos para as equipes de tecnologia da informação (TI).

O investimento em tecnologia portuária é outro fator impactante para esse processo. Os terminais portuários de Santos, por exemplo, possuem equipamentos de ponta que operam, em sua maioria, contêineres, granéis e cargas gerais com o objetivo de melhorar os indicadores de produtividade e tornar o processo mais eficiente. A chegada de outras cargas, como a de celulose, utiliza soluções semiautomatizadas, reforçando a necessidade de novas tecnologias operacionais.

Outro fator relevante para essa transformação é a capacitação dos profissionais portuários. De forma geral, o setor portuário tem grande preocupação em agregar valor por 
meio da mão de obra necessária para suas atividades. Trata-se de uma relação ganha-ganha, na qual as organizações olham o retorno sobre os investimentos (return on investments [ROI]) e os trabalhadores, sua ascensão na carreira. Não é à toa que as empresas mais competitivas do setor contam com um baixo turnover de pessoal.

Quem não está familiarizado com o setor ainda tem uma visão anterior à dos anos 1990 em relação ao trabalhador portuário, quando o serviço braçal era predominante. Até esse período, os portos de fato possuíam uma estrutura defasada e sucateada, com baixa adoção de tecnologia, dificultando a competitividade do modal e impactando as importações e exportações do país.

Na modernização dos portos, surgiram equipamentos de ponta, como o portêiner, um gigante que custa milhões e que jamais poderia ser operado por pessoas não qualificadas para tal.

Essa sofisticação tecnológica trouxe a necessidade de investir em pessoas para que a operação fosse feita de forma segura, eficiente e produtiva. Em 2013, a DP World Santos, por exemplo, quebrou barreiras ao contratar seus primeiros funcionários - sem experiência. A aposta deu certo: dos 700 integrantes dessa época, cerca de 500 continuam no terminal, e $86 \%$ já foram promovidos. Superado o primeiro desafio, o de contratações, a qualificação foi a próxima etapa em que a área de recursos humanos $(\mathrm{RH})$ passou a atuar a fim de preparar os integrantes para as novidades que chegavam ao setor.

Os profissionais portuários passaram por etapas não apenas restritas aos limites dos cais, mas também por formações no exterior. Entre 2012 e 2013, na ocasião do início das operações da empresa, uma parcela dos profissionais recém-contratados teve a oportunidade de participar de um intercâmbio para o Peru, em um programa de qualificação no Terminal Muelle Sur, no Porto da DP World em Callao, cidade próxima a Lima. No país vizinho, os profissionais foram capacitados a operar RTGs e QCs (portêineres), em treinamentos que misturavam teoria e prática.

Essa experiência abriu caminhos para que, posteriormente, se tornassem membros do Advanced Trainer \& Assessor Program (Atap) -, uma nomeação global da companhia que habilita operadores a capacitarem outros integrantes do grupo em maior escala. Foi o que aconteceu anos depois, quando os participantes do programa tiveram a oportuni- 
dade de contribuir para a capacitação de operadores de países que também estavam iniciando suas operações, como Moçambique e Equador.

\section{CONHECIMENTO ADQUIRIDO E ENSINADO}

O intercâmbio enquanto oportunidade valiosa de absorver e repassar conhecimentos e culturas não parou por aí. Às vésperas da inauguração do terminal, uma comitiva partiu de Santos com destino a Posorja, no Equador. Como parte do grupo, havia coordenadores de operações, operadores de equipamentos, planejadores de navio, supervisores de gate, gerente de manutenção e representantes de tecnologia da informação, que puderam ensinar e avaliar os seus formandos no início das operações da primeira instalação de águas profundas daquele país.

Graças aos bons resultados dessa experiência, aliados ao fomento de instituições educacionais, hoje o cenário de recrutamento e seleção é bem diferente. Conhecendo a realidade dos portos, os candidatos já chegam ao processo seletivo com algum nível de qualificação, seja para funções operacionais ou administrativas, o que proporciona uma facilidade para acessar esse mercado de trabalho.

Ademais, a era digital mudou significativamente o RH nos mais modernos portos brasileiros. A estratégia de captação de talentos passou a ser direcionada a uma geração bem mais conectada. Atualmente, bancos digitais organizados permitem conhecer o perfil do candidato antes mesmo da primeira fase da seleção.

Outras ferramentas, como entrevistas por vídeo, plataformas para testes e o armazenamento em nuvem, aumentam a velocidade da triagem, auxiliam na integração entre gestores e RH e dão informações mais precisas sobre a performance do candidato, possibilitando uma escolha assertiva para a vaga em questão.

Enfim, não é só a desestatização que irá mudar o cenário, mas outros fatores que acompanham esse movimento, como equipamentos de ponta, melhoria na infraestrutura, profissionais capacitados e melhoria da economia.

Essa cadeia logística poderá mudar o cenário portuário no Brasil. Um percurso que consista em desenvolver terminais mais eficientes, planejar as operações em menor tempo e custo, com atuação de mão de obra qualificada, proporcionará a desejada modernização dos portos. 